\title{
Synthesis of some nucleosides derivatives from L- rhamnose with expected biological activity
}

\author{
Amira Atef Ghoneim
}

\begin{abstract}
Practical procedures for production of variously blocked compounds from L-rhamnose have been developed. These compounds are highly useful as indirect $\beta$-L-rhamnosyl donors. This approach represents a new method for the synthesis of aromatic nucleoside analogues and the synthesis of $(3 S, 4 S, 5 S, 6 R) 3,4,5$-triacetoxy-2-methyl-7,9diaza-1-oxa-spiro $[4,5]$ decane-10-one-8-thione (7).
\end{abstract}

\section{Introduction}

Rhamnose is a component of the outer cell membrane of acid-fast bacteria in the Mycobacterium genus, which includes the organism that causes tuberculosis [1-3]. Rhamnose has no role in mammalian metabolism so that compounds which interfere specifically with rhamnose metabolism should not have any deleterious effect on humans. It is possible that a chemotherapeutic approach to the treatment of diseases induced by mycobacteria, such as tuberculosis and leprosy, would be to find compounds which inhibit either the biosynthesis of Tdp-rhamnose or its subsequent incorporation into the cell wall. The term spironucleoside was introduced in 1990 to designate a class of spiranic sugar derivatives in which the anomeric carbon belongs to both the sugar ring and to a heterocyclic base [4-6].

Data on this type of compound were reported before 1990 but, as far as we are aware, without using the term spironucleoside. Of the different classes of nucleosides, the spironucleosides are probably the least well known. In the last eight years, other syntheses of hydantocidin [5], spirofuranoid derivatives of different heterocycles [7], pyranoid analogues of hydantocidin [8].

\section{Results and Discussion}

2, 3, 4-Tri- $O$ - acetyl- $\beta$-L-rhamnopyranose bromide 3 (Scheme 1) obtained by a known procedure from tetra$\mathrm{O}$-acetyl-L-rhamnopyranose 2 with $\mathrm{HBr}$ in acetic acid [9] was treated with mercury(II) cyanide in dry

Correspondence: aa_amiraatef@yahoo.com

Chemistry Department, Faculty of Science, Zagazig University, Zagazig, Egypt nitromethane at room temperature to give 2,3,4-tri- $O$ acetyl- $\beta$-L-rhamnopyranose cyanide 4 .

For the partial hydrolysis of the nitrile moiety in 4 $\mathrm{HBr}$ in acetic acid [10] afforded the corresponding (2, 3, 4-tri- $O$ - acetyl- $\beta$-L-rhamnopyranose) formamide 5 after $3 \mathrm{~h}$ reaction time in $94 \%$ yield as an almost analytically pure crystalline product. The anomeric configuration of compounds $\mathbf{4}$ and $\mathbf{5}$ has been found to be $\beta$ according to the measured coupling constants between $\mathrm{H}-1$ and $\mathrm{H}-2\left(\mathrm{~J}_{1,2} \sim 6.3 \mathrm{~Hz}\right)$.

Photobromination of 5 with bromine in refluxing chloroform [11] gave $\mathbf{6}$ as an essentially pure product in an almost quantitative yield. Reaction of $\mathbf{6}$ with ammonium thiocyanate in nitromethane in the presence of elemental sulfur to suppress radical-mediated pathways [12] under nitrogen atmosphere gave spiro-thiohydantoin 7 . The structures of the new heterocyclic derivatives have been unequivocally established by ${ }^{1} \mathrm{HNMR}$ spectroscopy.

2, 3-O-Isopropylidene-L-rhamnopyranose 8 was synthesized according to the reported procedure [13]. L-rhamnose 1 was reaction with dry acetone in the presence of $p$-toluene sulfonic acid to give $\mathbf{8}$. The 2, 3-O-isopropylidene group is used extensively as a blocking group in nucleosides synthesis as a means of enhancing the volatility of polar nucleosides. The reaction of 2, 3-O-isopropylidene-L-rhamnopyranose 8 with malononitrile in the presence of ammonium hydroxide in methanol afforded the corresponding 3-(2, 3-O-isopropylidene- $\beta$-L-rhamnopyranose) iminopropanenitrile $\mathbf{9}$ (Scheme 2).

The structure of compound $\mathbf{9}$ was confirmed by their elemental analyses and spectral (IR, 1H NMR and MS) data (see Experimental Section). For example, their $1 \mathrm{H}$ 


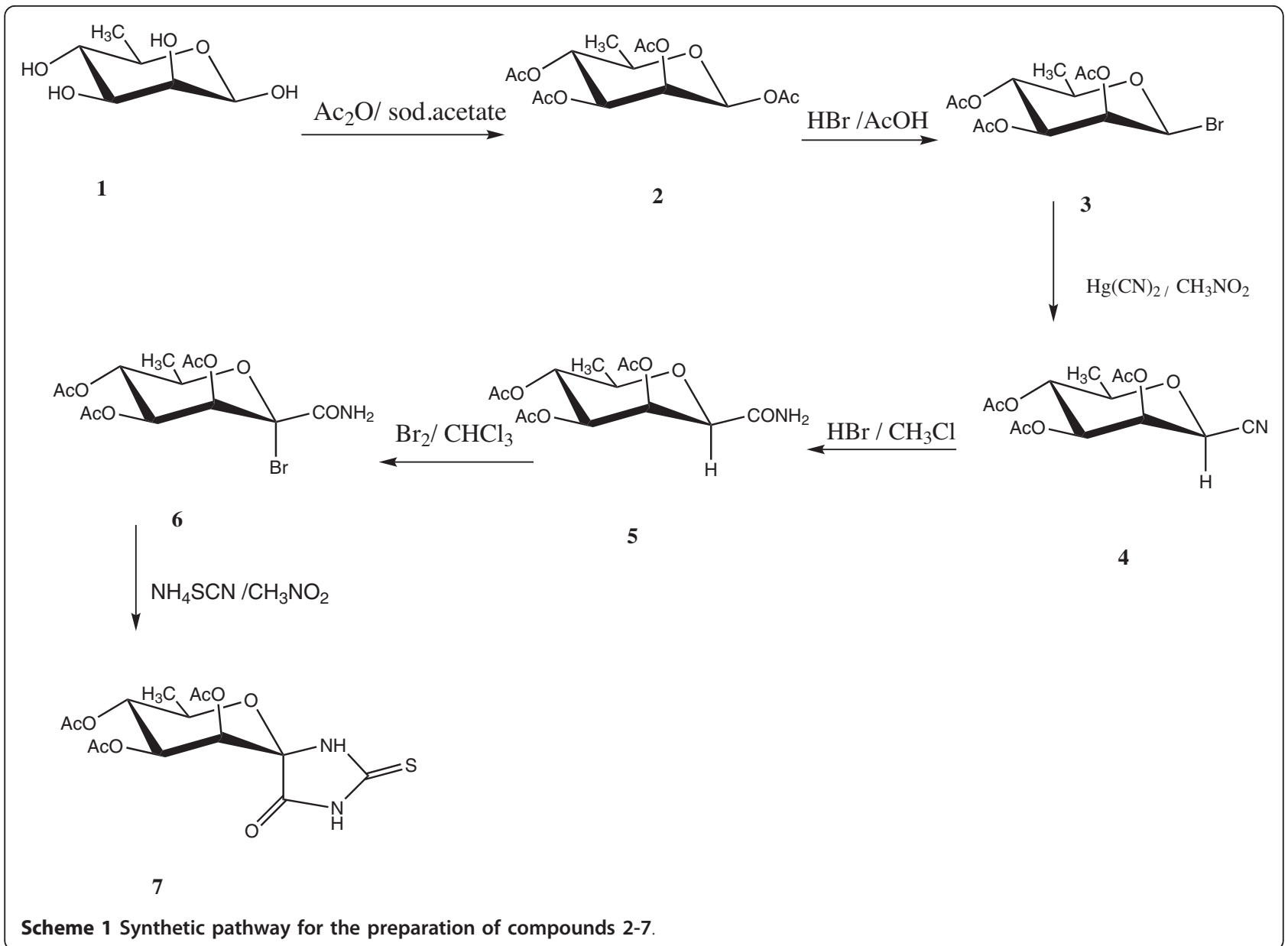

NMR spectra in DMSO-d6 revealed in each case, a characteristic signal in the region $\delta=7.28-7.34$ assignable to the azamethine $\mathrm{N}=\mathrm{CH}$ proton. This was reacted with thioglycolic acid in the presence of absolute ethanol yielded the corresponding 2-(6-(2, 3-O-isopropylidene- $\beta$-L-rhamnopyranose)-2-acetonitrile-3H-1, 3-thiazol4-one 10 (Scheme 3).

The compound $\mathbf{9}$ underwent nucleophilic addition with benzylidenemalononitrile in refluxing ethanol in the presence of piperdine afforded the corresponding substituted pyridine derivative $\mathbf{1 1}$ in good yield. The structure of $\mathbf{1 1}$ was confirmed on the basis of elemental analysis and spectral data. The formation of $\mathbf{1 1}$ is assumed to occur via initial formation of the Michael addition of the amino group in $\mathbf{9}$ to activate the double bond in benzylidenemalononitrile followed by intramolecular cyclization, and then it loses hydrogen cyanide to afford the Pyridine derivative 11 [14-16].

The formation of compound $\mathbf{1 1}$ may be proceeding through the following mechanism (Scheme 4). The reaction of compound 9 with carbon disulfide in the presence of pyridine afforded the corresponding 4-(2, 3-Oisopropylidene- $\beta$-L-rhamnopyranose)-6-amino- $2 \mathrm{H}-1$, 3-thiazine-2-thione 12 (Scheme 3). The structure of compound 12 was established by IR, ${ }^{1} \mathrm{HNMR}$ and mass spectrometry. IR spectra showed a peak at $1224 \mathrm{~cm}^{-1}$ indicative of $\mathrm{C}=\mathrm{S}$.

\section{Antibacterial activity}

The antibacterial activities of the synthesized compounds were determined by the well diffusion method [17]. In this work, Escherichia coli (ATTC-25922), Klebsiella pneumoniae (ATCC 10031), Bacillus cereus (ATTC10702), Salmonella typhimurium (ATTC-23564) were used to investigate the antibacterial activities. The prepared compounds were tested against the Gram positive bacteria (B. cereus) and Gram negative bacteria (E. coli). The bacterial liquid cultures were prepared in infusion broth for their activity tests. The compounds were dissolved in DMSO at concentration of $1 \mathrm{mg} \mathrm{ml}^{-1}$. Antibacterial activity of DMSO against the test organisms was investigated, and was found to be nil. Approximately $1 \mathrm{~cm}^{3}$ of a $24 \mathrm{~h}$ broth culture containing $10^{6} \mathrm{cfu} \mathrm{cm}^{-3}$ was placed in sterile Petri dishes. Molten nutrient agar $\left(15 \mathrm{~cm}^{3)}\right.$, kept at $45^{\circ} \mathrm{C}$, was then poured into the Petri dishes and allowed to solidify. Six millimeter diameter 


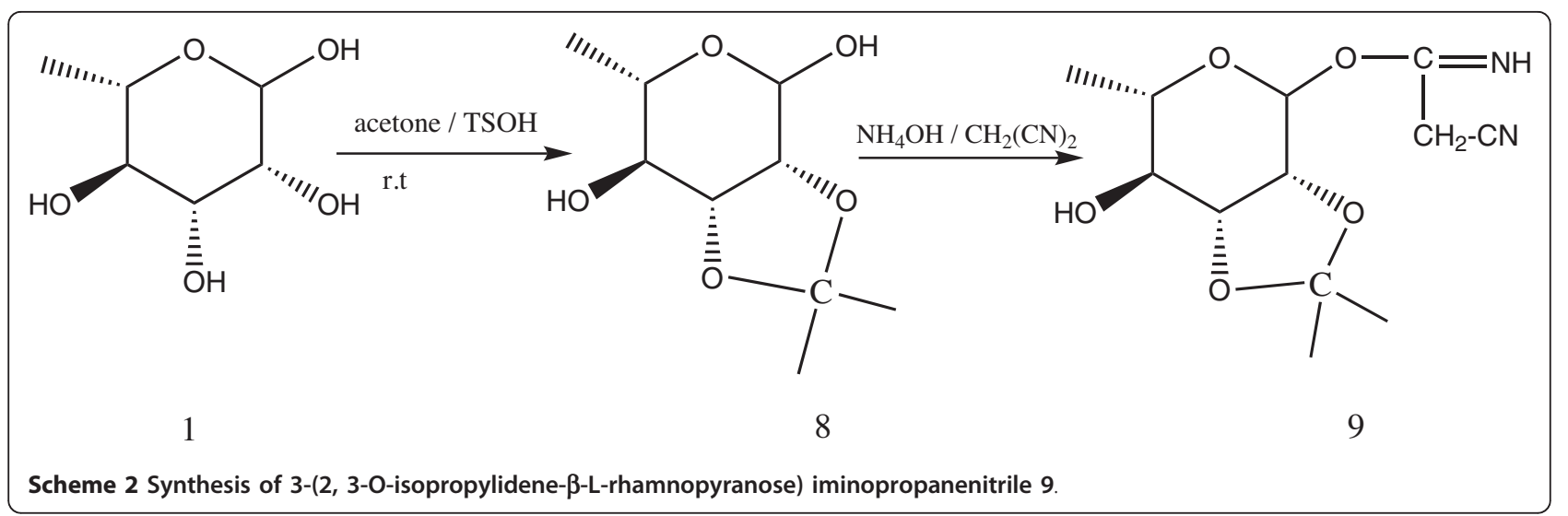

holes were then punched carefully using a sterile cork borer and completely filled with the test solutions. The plates were incubated for $24 \mathrm{~h}$ at $37^{\circ} \mathrm{C}$. After $24 \mathrm{~h}$, the inhibition zone that appeared around the holes in each plate was measured. Antibacterial activity was determined by measuring the diameter of inhibition zone. Activity of each compound was compared with ciprofloxacin and sulphamethoxazol as standards $[18,19]$.
These results are summarized in Table 1 . The examination data (Table 1) reveals that most of compounds showed excellent antibacterial activity when compared with ciprofloxacin and sulphamethoxazol. From the results, it is obvious that compound 7 showed the highest degree of inhibition against Salmonella typhi, Klebsiella Pneumnoiae Escherichia coli EC and Bacillus subtilis BS. Moreover, compounds $\mathbf{9}$ and $\mathbf{1 1}$ have weak inhibition against Escherichia coli and Bacillus Cereus. While

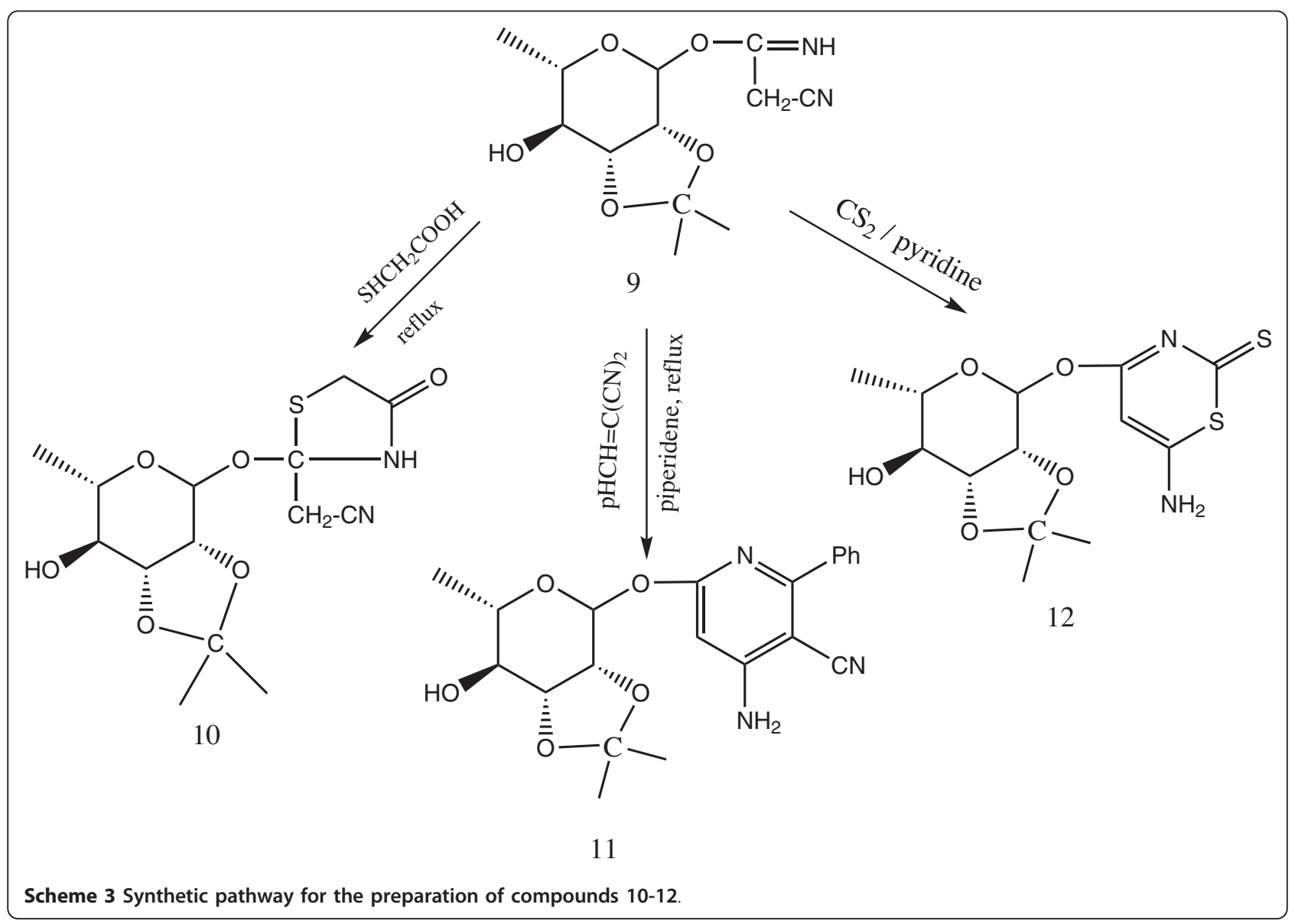




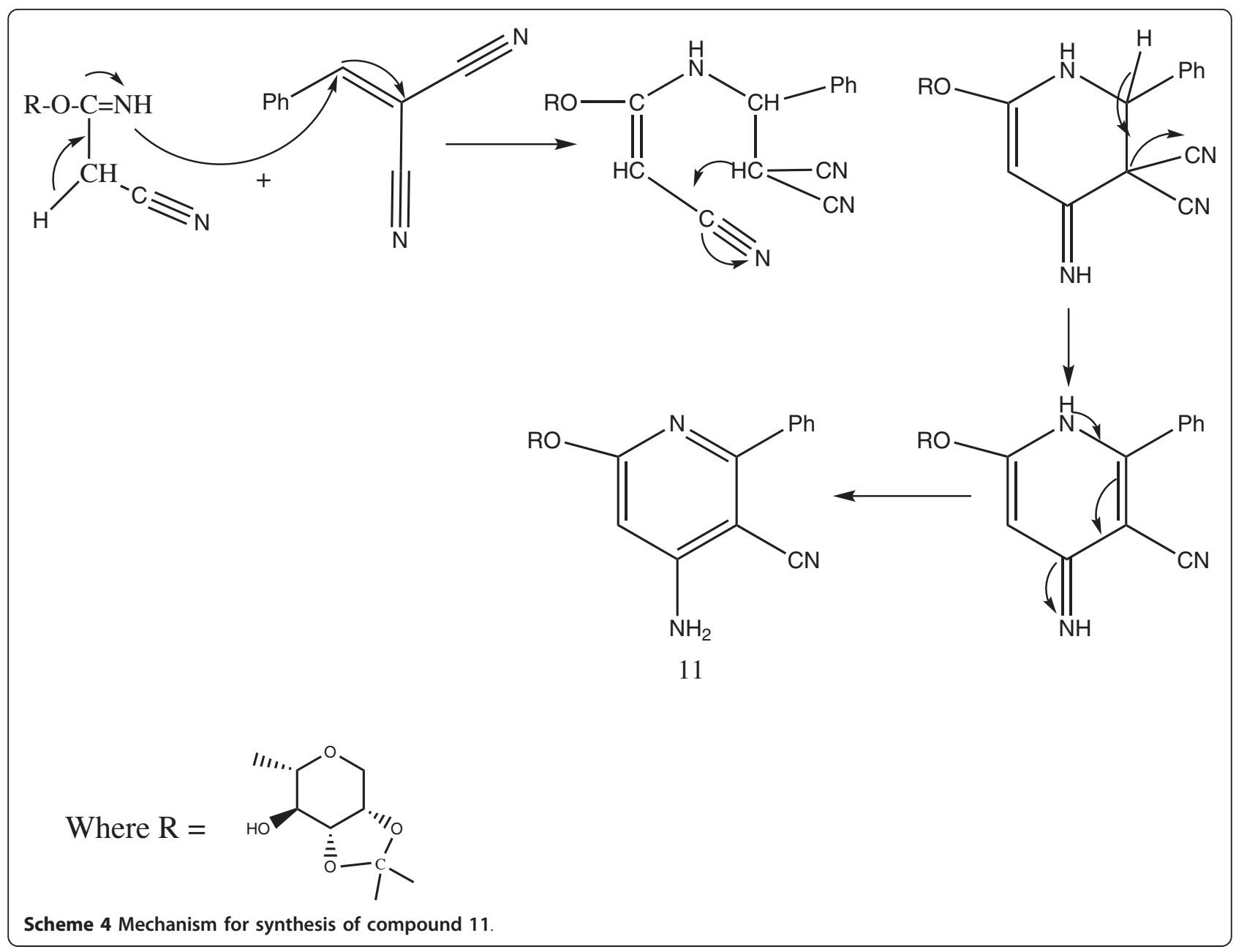

10 had a considerable degree of inhibition against Bacillus Cereus and Klebsiella Pneumnoiae, compounds 9 and $\mathbf{1 0}$ had only weak inhibition against Escherichia coil EC.

\section{Experimental Section}

Melting points were determined with an Electro Thermal Mel-Temp II apparatus and are all uncorrected.
IR spectra were obtained in the solid state as potassium disc using a Perkin-Elmer model 1430 Spectrometer. ${ }^{1} \mathrm{H}$ NMR were recorded on aVarian/Gemini 200/MHZ spectrometer in DMSO- $\mathrm{d}_{6}$ as a solvent and TMS as an internal standard (chemical shift in $\delta, \mathrm{ppm}$ ). Mass spectra were measured on an instrument "VG-7035" spectra were recorded at 70 or 15 electron volt. Elemental

Table 1 Results of antibacterial activity of the tested compounds

\begin{tabular}{|c|c|c|c|c|c|}
\hline \multirow[b]{3}{*}{ Compound } & \multicolumn{5}{|c|}{ Microorganisms } \\
\hline & \multicolumn{5}{|c|}{ Antibacterial activity (in $\mathrm{mm} /$ conc. $1 \mathrm{mg} / \mathrm{ml}^{-1}$ ) } \\
\hline & $\begin{array}{c}\text { Salmonella } \\
\text { typhi }\end{array}$ & $\begin{array}{c}\text { Klebsiella } \\
\text { Pneumnoiae }\end{array}$ & $\begin{array}{l}\text { Bacillus } \\
\text { subtilis }\end{array}$ & $\begin{array}{l}\text { Escherichia } \\
\text { coil }\end{array}$ & $\begin{array}{l}\text { Bacillus } \\
\text { Cereus }\end{array}$ \\
\hline 7 & 9 & 8 & 7 & 8 & 8 \\
\hline 9 & 6 & 7 & 6 & 2 & 5 \\
\hline 10 & 4 & 7 & 4 & 4 & 6 \\
\hline 11 & 8 & 3 & 8 & 3 & 3 \\
\hline 12 & 7 & 5 & 6 & 8 & 7 \\
\hline Sulphamethoxazol & 23 & 23 & 21 & 19 & 18 \\
\hline Ciprofloxacin & 8 & 10 & 10 & 9 & 15 \\
\hline
\end{tabular}


analysis was performed at the Micro analytical centre, Cairo University, Giza, Egypt.

\section{2, 3, 4-Tri-O-acetyl- $\beta$ - L-rhamnopyranosyl cyanide (4)}

Acetobromo-rhamnose $3(1.89 \mathrm{~g}, 1.5 \mathrm{mmol})$ was dissolved in dry nitromethane $(40 \mathrm{ml})$ and mercury (II) cyanide $(0.79 \mathrm{~g}, 1.5 \mathrm{mmol})$ was added. The mixture was stirred at r.t for 2 days. The solids were then filtered off, washed with nitromethane, and the solvent was removed from the combined filtrate and washings. The residue was dissolved in chloroform, the solution filtered if necessary and washed with aqueous potassium bromide solution, after drying the solvent was removed and the remaining syrup was crystallized from diethyl ether to give compound 4 in pure form (56\% yield). M.p. 104$106^{\circ} \mathrm{C}$. IR (KBr) v $v_{\max }: 2926$ (aliphatic $\mathrm{CH}$ ), 2219 $(\mathrm{CN}), 1728(\mathrm{C}=\mathrm{O}), 1078(\mathrm{C}-\mathrm{O}) \mathrm{cm}^{-1} ;{ }^{1} \mathrm{H}$ NMR $\left(500 \mathrm{MHz}, \mathrm{CDCl}_{3}\right) \delta 5.67(\mathrm{~d}, \mathrm{~J} 1,2=6.3 \mathrm{~Hz}, 1 \mathrm{H}, \mathrm{H}-1)$, 4.23-4.05 (dd, 3H, H-2,3,4), 4.38 (ddd, $J=6.1,6.2,10.0$, $1 \mathrm{H}, \mathrm{H}-5) ; 1.73$ (s, 9H; $\left.\mathrm{CH}_{3} \mathrm{COO}\right), 1.34(\mathrm{~d}, J=6.2 \mathrm{~Hz}, 3 \mathrm{H}$, $\mathrm{CH}_{3}$ ). Anal. Calcd. for $\mathrm{C}_{13} \mathrm{H}_{17} \mathrm{NO}_{7}$ (299.28): C, 52.17; H, 5.73; N, 4.68. Found: C, 52.05; H 5.67; N, 4.54 .

\section{( 2,3 , 4-Tri-O- acetyl- $\beta$-L-rhamnopyranosyl) formamide (5)}

Rhamnosyl cyanide $4(1.1 \mathrm{~g}, 0.20 \mathrm{mmol})$ was suspended in a solution of hydrogen bromide in acetic acid $(5 \mathrm{ml}$, $20 \% \mathrm{~m} / \mathrm{m}$ ) and the mixture was stirred at r.t for $3 \mathrm{~h}$. The resulting solution was poured into ice-water $(50 \mathrm{ml})$, which was then extracted with chloroform $(2 \times$ $50 \mathrm{ml}$ ). The unified $\mathrm{CHCl}_{3}$ phases were washed with saturated aqueous sodium bicarbonate $(2 \times 50 \mathrm{ml})$, then with water $(20 \mathrm{ml})$, dried, and the solvent removed and give the crystalline residue 5 (94\%, yield). M.p. $226-228^{\circ} \mathrm{C}$. IR (KBr) v max $_{\text {ax }} 3342(\mathrm{NH}), 2950$ (aliphatic $\left.\mathrm{CH}\right), 1702(\mathrm{C}=$ O ester), 1684 ( $\mathrm{C}=\mathrm{O}$ amide), $1078(\mathrm{C}-\mathrm{O}) \mathrm{cm}^{-1} ;{ }^{1} \mathrm{H}$ NMR $\left(500 \mathrm{MHz}, \mathrm{CDCl}_{3}\right) \delta 6.52\left(\right.$ br s, $2 \mathrm{H}, \mathrm{CONH}_{2}$ ), $4.26(\mathrm{~d}, \mathrm{~J} 1$, $2=6.1 \mathrm{~Hz}, 1 \mathrm{H}, \mathrm{H}-1), 4.20$ (ddd, $J=6.1,6.2,9.7 \mathrm{~Hz}, 1 \mathrm{H}$, $\mathrm{H}-5), 1.83$ (s, 9H; $\mathrm{CH}_{3} \mathrm{COO}$ ), $1.35\left(\mathrm{~d}, J=6.1 \mathrm{~Hz}, 3 \mathrm{H}, \mathrm{CH}_{3}\right.$ ). Anal. Calcd. for $\mathrm{C}_{13} \mathrm{H}_{19} \mathrm{NO}_{8}$ (317.29): C, 49.21; $\mathrm{H}, 6.04 ; \mathrm{N}$, 4.41. Found: C 49.39, H 5.59; N 4.37.

\section{$(2,3$, 4-Tri-O-acetyl-1-bromo-1-deoxy- $\beta$-L- rhamnopyranosyl) formamide (6)}

Rhamnosyl formamide 5 (200 $\mathrm{mg}, 0.32 \mathrm{mmol}$ ) was dissolved in chloroform $(6 \mathrm{ml})$, bromine $(0.07 \mathrm{ml}, 1.28$ $\mathrm{mmol}$ ) and some barium carbonate were added, and the mixture was irradiated and refluxed by a heat lamp. After $1 \mathrm{~h}$ the mixture decolorized and $0.1 \mathrm{ml} \mathrm{Br} 2$ was added again. This was repeated after another $0.5 \mathrm{~h}$. After TLC had shown complete transformation $(\sim 2 \mathrm{~h}$ from the start) the mixture was filtered, washed with $5 \%$ aqueous sodium bisulphate and saturated aqueous sodium bicarbonate solutions, dried, and the solvent removed. The residual syrup $(264 \mathrm{mg})$ crystallized on addition of diethyl ether to give 6. M.p. $181-183^{\circ} \mathrm{C}$. IR $(\mathrm{KBr}) v_{\max }: 3343(\mathrm{NH}), 1735(\mathrm{C}=\mathrm{O}$ ester $), 1672(\mathrm{C}=\mathrm{O}$ amide), $1088(\mathrm{C}-\mathrm{O}) \mathrm{cm}^{-1}$; $1 \mathrm{H}$ NMR $\left(500 \mathrm{MHz}, \mathrm{CDCl}_{3}\right) \delta$ (ppm) $6.63\left(\right.$ br s, $\left.1 \mathrm{H}, \mathrm{CONH}_{2}\right), 6.14(\mathrm{~d}, \mathrm{~J} 1,2=6.3 \mathrm{~Hz}$, $1 \mathrm{H}, \mathrm{H}-1), 4.31$ (dd, 1H, H-4), 4.36 (dd, 1H, H-2), 4.72 (ddd, $1 \mathrm{H}, J=6.1,6.2,10.1 \mathrm{~Hz}, \mathrm{H}-5), 1.73(\mathrm{~s}, 9 \mathrm{H}$; $\left.\mathrm{CH}_{3} \mathrm{COO}\right), 1.24\left(\mathrm{~d}, J=5.9 \mathrm{~Hz}, 3 \mathrm{H}, \mathrm{CH}_{3}\right)$. Anal. Calcd. for $\mathrm{C}_{13} \mathrm{H}_{18} \mathrm{NO}_{8} \mathrm{Br}$ (396.19): C, 39.41; H, 4.58; N, 3.54. Found: C 39.58; H 4.46; N 3.43.

\section{$(3 S, 4 S, 5 S, 6 R)$ 3, 4, 5-triacetoxy-2-methyl-7, 9-diaza-1-} oxa-spiro $[4,5]$ decane-10-one-8-thione (7)

1-Bromorhamnosyl) formamide $6(2 \mathrm{~g}, 3.69 \mathrm{mmol})$ was dissolved in dry nitromethane $(23 \mathrm{ml})$. Molecular sieves (3 $\mathrm{A})$, ammonium thiocyanate $(0.732 \mathrm{~g}, 1.79 \mathrm{mmol})$ and elemental sulfur ( $4 \mathrm{mg}, 0.26 \mathrm{mmol}$ ) were added, and the mixture was stirred in an $80^{\circ} \mathrm{C}$ bath under nitrogen atmosphere for $7 \mathrm{~h}$. The syrup residue obtained after filtration and solvent removal was dissolved in dichloromethane, the solution filtered, washed with saturated aqueous $\mathrm{NH}_{4} \mathrm{Cl}$ solution, dried, and concentrated. The remaining syrup was separated by silica gel column chromatography with ethyl acetate: hexane 2:5 eluent, the first fraction which crystallized from methanol to give $0.99 \mathrm{~g}$ of thiohydantoin 7. M.p. 199-202 ${ }^{\circ} \mathrm{C}$. IR (KBr) $v_{\max }: 3342(\mathrm{NH}), 1649$ (C = O amide), $1078(\mathrm{C}-\mathrm{O}) \mathrm{cm}^{-1} ;{ }^{1} \mathrm{H}$ NMR $\left(500 \mathrm{MHz}, \mathrm{CDCl}_{3}\right) \delta(\mathrm{ppm})$ $9.08(\mathrm{~s}, 1 \mathrm{H}, \mathrm{NH}), 3.67$ (d, $1 \mathrm{H}, \mathrm{H}-4), 5.95$ (ddd, $1 \mathrm{H}, J=6.0$, 6.1, $9.8 \mathrm{H}-5), 3.91$ (d, $1 \mathrm{H}, \mathrm{H}-3), 1.38$ (d, $J=6.2 \mathrm{~Hz}, 3 \mathrm{H}$, $\mathrm{CH}_{3}$ ). Anal. Calcd. for $\mathrm{C}_{14} \mathrm{H}_{18} \mathrm{~N}_{2} \mathrm{O}_{8} \mathrm{~S}$ (374.37): C, 44.92; H, 4.85; N, 7.48. Found: C, 44.78; H, 4.76; N, 7.34.

\section{2, 3-0-isopropylidene-L-rhamnopyranos (8)}

The reaction mixture of L-rhamnose monohydrate $(1 \mathrm{~g}$; $5.5 \mathrm{mmol})$, dry acetone $(50 \mathrm{~mL})$, toluene-4-sulphonic acid monohydrate $(100 \mathrm{mg})$ and 2, 2-dimethoxypropane $(6.8 \mathrm{~mL} ; 55 \mathrm{mmol})$ was stirred for $6 \mathrm{~h}$. The reaction mixture was neutralized by the addition of sodium carbonate. The neutral mixture was filtered, washed with methanol and evaporated. A syrupy isopropylidene derivative was purified by column chromatography on silica gel. TLC indicated one major product 8 isolated as syrup. Yield $0.73 \mathrm{~g}(65 \%) ; \mathrm{Rf}=0.55$. IR $(\mathrm{KBr}) v_{\max }$ : 3432-3350 (OH), $1078(\mathrm{C}-\mathrm{O}) \mathrm{cm}^{-1}$; ${ }^{1} \mathrm{H}-\mathrm{NMR}(500 \mathrm{MHz}$, $\left.\mathrm{CDCl}_{3}\right) \delta(\mathrm{ppm}) 5.65(\mathrm{~d}, 1 \mathrm{H}, \mathrm{H} 1), 4.56(\mathrm{~s}, 1 \mathrm{H}, \mathrm{OH})$, 4.16-3.79 (dd, $4 \mathrm{H}, \mathrm{H}-2,3,4,5), 1.53\left(\mathrm{~s}, 6 \mathrm{H}, 2 \mathrm{CH}_{3}\right), 1.36$ $\left(3 \mathrm{H}, \mathrm{d}, J=6.2 \mathrm{~Hz}, \mathrm{CH}_{3}\right)$. Anal. Calcd. for $\mathrm{C}_{9} \mathrm{H}_{16} \mathrm{O}_{5}$ (204.22): C, 52.93; H, 7.90. Found: C, 52.89; H, 7.86.

\section{3-(2, 3-O-isopropylidene- $\beta$-L-rhamnopyranose) iminopropanenitrile (9)}

A mixture of 2, 3- $O$-isopropylidene- $\beta$-L-rhamnopyranose 8 (0.25 g, 1.65 mmole), malononitrile $(0.48 \mathrm{~g}, 0.73$ mmole), methanol $(10 \mathrm{ml})$ and $6 \mathrm{M} \mathrm{NH}_{4} \mathrm{OH}(2 \mathrm{ml})$ was heated at $50^{\circ} \mathrm{C}$ for 3 days. The reaction was cooled to 
$10^{\circ} \mathrm{C}$ and kept at this temperature overnight. The solvent was evaporated under reduced pressure and the residue recrystallized by methanol/diethyl ether to afford a brown crystals $\left(67 \%\right.$ yield). M.p. $220-224^{\circ} \mathrm{C}$. IR (KBr) $v_{\max }: 3412(\mathrm{OH}), 3150(\mathrm{NH}), 2021(\mathrm{CN}), 1634(\mathrm{C}=\mathrm{N})$, $1078(\mathrm{C}-\mathrm{O}) \mathrm{cm}^{-1} ;{ }^{1} \mathrm{H}-\mathrm{NMR}\left(500 \mathrm{MHz}, \mathrm{CDCl}_{3}\right) \delta(\mathrm{ppm})$ $7.28(\mathrm{~s}, 1 \mathrm{H}, \mathrm{NH}), 5.65(\mathrm{~d}, 1 \mathrm{H}, \mathrm{H} 1), 4.56(\mathrm{~s}, 1 \mathrm{H}, \mathrm{OH})$, 4.16-3.79 (dd, $4 \mathrm{H}, \mathrm{H}-2,3,4,5), 2.53\left(\mathrm{~s}, 2 \mathrm{H}, \mathrm{CH}_{2}-\mathrm{CN}\right)$, $1.27\left(\mathrm{~d}, J=5.9 \mathrm{~Hz}, 3 \mathrm{H}, \mathrm{CH}_{3}\right), 1.53\left(\mathrm{~s}, 6 \mathrm{H}, 2 \mathrm{CH}_{3}\right)$. Anal. Calcd. for $\mathrm{C}_{12} \mathrm{H}_{18} \mathrm{~N}_{2} \mathrm{O}_{5}$ (270.28): C, 53.33; H, 6.71; N, 10.36. Found: C, 53.42; H, 6.52; N, 10.17 .

\section{2-(6-(2, 3-O-isopropylidene- $\beta$-L-rhamnopyranose)-2- acetonitrile-3H-1, 3-thiazol-4-one (10)}

Compound 9 (0.3 g, $1.1 \mathrm{mmole})$, absolute ethanol $(50 \mathrm{ml})$ and thioglycolic acid $(2 \mathrm{ml})$ were refluxed $6 \mathrm{hrs}$. The solvent was evaporated, and the residue dissolved in chloroform the solution washed with sodium bicarbonate solution. The organic layer was evaporated to give compound 10 (57\% yield). M.p. $205-208^{\circ} \mathrm{C}$. IR ( $\mathrm{KBr}$ ) $v_{\max }: 3386(\mathrm{OH}), 3250(\mathrm{NH}), 2205(\mathrm{CN}), 1645(\mathrm{C}=$ $\mathrm{O}), 1078(\mathrm{C}-\mathrm{O}) \mathrm{cm}^{-1} ;{ }^{1} \mathrm{H}-\mathrm{NMR} 500 \mathrm{MHz} \delta 7.25(\mathrm{~s}, 1 \mathrm{H}$, $\mathrm{NH}), 6.13(\mathrm{~s}, 1 \mathrm{H}, \mathrm{H} 1), 5.98(\mathrm{~s}, 1 \mathrm{H}, \mathrm{OH}), 4.21(\mathrm{~s}, 2 \mathrm{H}$, $\mathrm{CH}_{2}$ ), 3.91-4.23 (m, 3H, H-2, 3, 4), 3.26 (s, $2 \mathrm{H}, \mathrm{CH}_{2}-\mathrm{S}$ ). Anal. Calcd. for $\mathrm{C}_{12} \mathrm{H}_{18} \mathrm{~N}_{2} \mathrm{O}_{5}$ (270.28): C, 53.33; H, 6.71; N, 10.36. Found: C, 53.12; H, 6.62; N, 10.12 .

\section{6-(2', 3'-O-isopropylidene- $\beta$-L-rhamnopyranose)-4-amino- 2-phenylpyridine-3-carbonitrile (11)}

A mixture of 9 (1.48 g, $5.48 \mathrm{~mol}$ ) and benzylidenemalononitrile $(0.54 \mathrm{~g}, 6 \mathrm{~mol})$ in piperidene $(10 \mathrm{~mL})$ was refluxed for $3 \mathrm{~h}$. The reaction mixture was then allowed to cool at room temperature. The solid product so formed was collected by filtration and recrystallized from ethanol as brown crystals, (71\% yield). M.p. 258$262^{\circ} \mathrm{C}$. IR $(\mathrm{KBr}) v_{\max } 3264-3435\left(\mathrm{NH}_{2}, \mathrm{OH}\right), 2109(\mathrm{CN})$, $1651(\mathrm{C}=\mathrm{N}) \mathrm{cm}^{-1} ;{ }^{1} \mathrm{HNMR}(500 \mathrm{MHz}$, DMSO-d6): $\delta$ 7.20-7.99 (m, $5 \mathrm{H}, \mathrm{Ar}-\mathrm{H}), 5.20$ (brs, $\left.2 \mathrm{H}, \mathrm{NH}_{2}\right), 5.83$ (s, $1 \mathrm{H}, \mathrm{H} 1), 5.52(\mathrm{~s}, 1 \mathrm{H}, \mathrm{OH}), 1.97(\mathrm{~d}, J=6.3 \mathrm{~Hz}, 3 \mathrm{H}$, $\mathrm{CH}_{3}$ ). Anal. Calcd. for $\mathrm{C}_{22} \mathrm{H}_{27} \mathrm{~N}_{3} \mathrm{O}_{5}$ (413.47): C, 63.91; H, 6.58; N, 10.16. Found: C, 63.40; H, 6.52; N, 10.07 .

\section{4-(2, 3-O-isopropylidene- $\beta$-L-rhamnopyranose)-6-amino- $2 \mathrm{H}-1$, 3-thiazine-2-thione (12)}

A mixture of $90.5 \mathrm{~g}(1.85 \mathrm{~mol})$ was suspended in absolute ethanol and anhydrous pyridine $(0.3 \mathrm{ml})$ and carbon disulphide $0.5 \mathrm{~mol}(0.6 \mathrm{~g})$ were added slowly. The mixture was stirred under reflux for $1 \mathrm{~h}$ and later heated at $75-80^{\circ} \mathrm{C}$ for $4 \mathrm{~h}$. Solvent was removed and the residue was dissolved in water $(80 \mathrm{~mL})$, acidified with concentrated hydrochloric acid to give a white precipitate, filtered and washed with ethanol. The precipitate recrystallized from chloroform/ ethanol to give white needles (84\% yields). M.p. $236-238^{\circ} \mathrm{C}$. IR (KBr) v $v_{\text {max: }} 3347-3258\left(\mathrm{NH}_{2}, \mathrm{OH}\right), 1580,1238,1224$ (C
= S) cm-1; ${ }^{1} \mathrm{HNMR}(500 \mathrm{MHz}, \mathrm{DMSO}) \delta 5.65(\mathrm{~s}, 1 \mathrm{H}, \mathrm{H}-1)$, 4.29-3.64 (d, $4 \mathrm{H}, \mathrm{H}-2,3,4,5), 4.16\left(\mathrm{~s}, 2 \mathrm{H}, \mathrm{NH}_{2}\right), 2.54(\mathrm{~s}$, $1 \mathrm{H}, \mathrm{OH}), 1.23\left(\mathrm{~d}, J=6.1 \mathrm{~Hz}, 3 \mathrm{H}, \mathrm{CH}_{3}\right), 1.40\left(\mathrm{~s}, 6 \mathrm{H}, 2 \mathrm{CH}_{3}\right)$. Anal. Calcd. for $\mathrm{C}_{20} \mathrm{H}_{27} \mathrm{~N}_{2} \mathrm{O}_{5} \mathrm{~S}_{2}$ (439.57): C, 54.65; H, 6.19; N, 6.37; S, 14.59. Found: C, 54.62; H, 6.32; N, 6.24; S, 14.53 .

\section{Conclusion}

In conclusion, the preparation procedure follow in this work for synthesis of some nucleosides derivatives from L- rhamnose with expected biological activity show operation simplicity, cleaner reaction, easy work-up and improved yields. Spectroscopic and elemental analysis confirms the proposed structures of these compounds. The prepared compounds showed promising antibacterial activity against Gram-positive bacteria Bacillus cereus.

\section{Acknowledgements}

The author is grateful to Zagazig University and the Deanship of Scientific Research. He also offers his thanks to the Faculty of Science and Department of Chemistry for their support.

\section{Competing interests}

The author declares that they have no competing interests.

Received: 30 September 2010 Accepted: 11 February 2011 Published: 11 February 2011

\section{References}

1. McNeil M, Daffe M, Brennan PJ: Evidence for the nature of the link between the arabinogalactan and peptidoglycan components of mycobacterial cell walls. J Biol Chem 1990, 265:18200-18206.

2. Daffe M, Brennan PJ, McNeil M: Predominant structural features of the cell wall arabinogalactan of Mycobacterium tuberculosis as revealed through characterization of oligoglycosyl alditol fragments by gas chromatography/mass spectrometry and by $1 \mathrm{H}$ and $13 \mathrm{C}$ NMR analyses. J Biol Chem 1990, 265:6734-43.

3. Besra GS, Khoo KH, McNeil MR, Dell A, Morris HR, Brennan PJ: A new interpretation of the structure of the mycolyl-arabinogalactan complex of Mycobacterium tuberculosis as revealed through characterization of oligoglycosylalditol fragments by fast-atom bombardment mass spectrometry and $1 \mathrm{H}$ nuclear magnetic resonance spectroscopy. Biochemistry 1995, 34:4257-4266.

4. Fernandez-Bolanos J, Blasco Lo 'pez A, Fuentes Mota J: Synthesis of (5S,8R,9R,10S)-8,9,10-trihydroxy-2-thioxo-1,6-dioxa-3-azaspiro[4.5]decane from 1-amino-1-deoxy-D- arabino-hexulose. Carbohydr Res 1990, 199:239-242.

5. Matsumoto M, Kirihara M, Yoshino T, Katoh T, Terashima S: A novel biogenetic type synthesis of (+)-hydantocidin. Tetrahedron Lett 1993, 34:6289-6292.

6. Chemla P: Stereoselective synthesis of (+)-hydantocidin. Tetrahedron Lett 1993, 34:7391-7394.

7. Estevez JC, Burton JW, Estevez RJ, Andron H, Wormald MR, Dwek RA, Brown D, Fleet GWJ: Spirodiketopiperazines of mannofuranose: carbopeptoid a-amino acid esters at the anomeric position of mannofuranose. J Tetrahedron Asymmetry 1998, 9:2137-2154.

8. Osz E, Sos E, Somsak L, Szila'gyi L, Dinya Z: A straightforward route to hydantocidin analogues with pyranose ring structure. Tetrahedron 1997, 53:5813-5824.

9. Lockhoff O: Acetale als anomere zentren von kohlenhydraten (Hal/Ound O/O-Acetale). In Methoden der organischen Chemie (Houben-Weyl). Volume E14a/3. Edited by: Hagemann H, Klamann D. Thieme: Stuttgart; 1992:708.

10. Myers RW, Lee YC: Synthesis of diazomethyl $\beta$-D-galactopyranosyl and $\beta$ D-glucopyranosyl ketones; Potential affinity-labeling reagents for carbohydrate-binding proteins. Carbohydrate Research 1986, 152:143-158. 
11. Somsák L, Batta G, Farkas I: Preparation of acetylated C-(1-bromo-Dglycosyl) heterocycles and 1-bromo-D-glycosyl cyanides. Carbohydrate Research 1983, 124:43-51.

12. Smith MD, Long DD, Martín A, Campbell N, Blériot Y, Fleet GWJ: Tetrahydrofuran a-Azido Esters: Precursors of Anomeric a-Amino Acid Monomers via Radical Bromination. Synlett 1999, 1151-1153.

13. Wheatley JR, Beacham AR, Lilley PM de Q, Watkin DJ, Fleet GWJ: Ketals of L-rhamnoheptonolactones: Potential mimics of L-rhamnose. Tetrahedron Asymm 1994, 5:2523-2534.

14. Al-Omran F, El-Khair AA, Mohareb RM: Synthesis and biological effects of new derivatives of benzotriazole as antimicrobial and antifungal agents. J Heterocycl Chem 2002, 39:877-883.

15. Al-Omran F, El-Khair AA: Novel synthesis of thieno[2,3-b]pyridine and substituted 2-thienylthiourea derivatives as antibiotic agents. $J$ Heterocycl Chem 2004, 41:909-914.

16. Kandeel ZE: Nitriles in heterocyclic synthesis: A novel synthesis of some thieno[2,3-d]pyrimidine and thieno[2,3-b]pyridine derivatives. Heteroat Chem 1996, 7:29-33.

17. Fenlon $\mathrm{CH}$, Cynamon $\mathrm{MH}$ : Comparative in vitro activities of ciprofloxacin and other 4-quinolones against Mycobacterium tuberculosis and Mycobacterium intracellulare. Antimicrob Agents Chemother 1986, 29:386-388.

18. Davis R, Markham A, Balfour JA: Ciprofloxacin, an updated review of its pharmacology, therapeutic efficacy and tolerability. Drugs 1996, 51:1019-74.

19. Palekar VS, Damle AJ, Shukla SR: Synthesis and antibacterial activity of some novel bis-1,2,4-triazolo[3,4-b]-1,3,4-thiadiazoles and bis-4thiazolidinone derivatives from terephthalic dihydrazide. Eur J Med Chem 2001, 44:5112-6.

doi:10.1186/1752-153X-5-7

Cite this article as: Ghoneim: Synthesis of some nucleosides derivatives from L- rhamnose with expected biological activity. Chemistry Central Journal 2011 5:7.

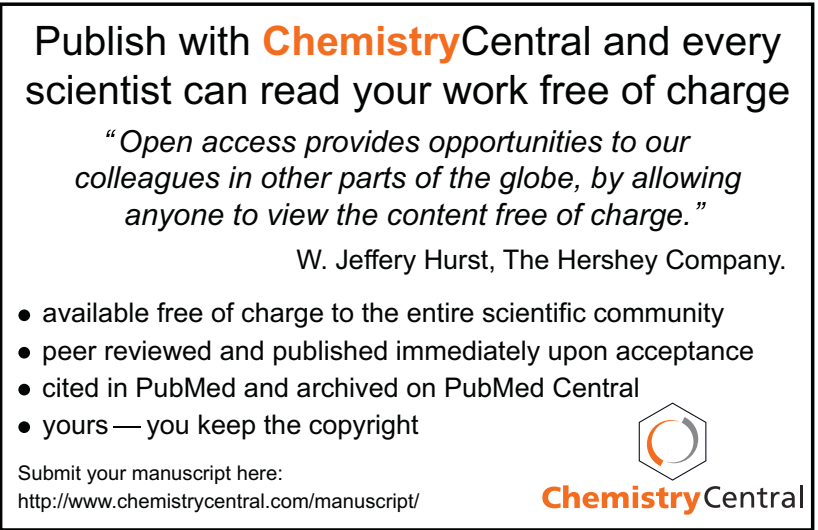

